\title{
Influence of mining related activities on levels of mercury in water, sediment and fish from the Ankobra and Tano River basins in South Western Ghana
}

Noah Kyame Asare-Donkor ${ }^{*}$ and Anthony Apeke Adimado

\begin{abstract}
Background: Mercury $(\mathrm{Hg})$ used in gold amalgamation is a major source of contamination in developing countries. The present study evaluates the concentrations of total mercury in water, sediment and fish from the Ankobra and Tano Rivers, which drain the major gold mining areas in Ghana. Total mercury (T-Hg) analysis was carried out using an atomic absorption spectroscopy (Perkin Elmer model 5100PC) equipped with a flow injection analysis system (FIAS, AS-90).

Results: Water, sediment and fish T-Hg concentrations were $0.145-1.078 \mu \mathrm{g} / \mathrm{L}, 23.39-73.31$, and $0.03-0.443 \mu \mathrm{g} / \mathrm{g} \mathrm{dw}$, respectively in Ankobra basin, while in Tano basin levels of $0.214-0.250 \mu \mathrm{g} / \mathrm{L}, 14.43-21.51,0.068-0.413 \mu \mathrm{g} / \mathrm{g}$ were found for water, sediment and fish, respectively. The T-Hg concentration in water from both basins were within the World Health Organization threshold limits for drinking water except at River Asuo Kofi. Concentration of T-Hg in the sediment exceeded Environmental Protection Agency ecotoxicological threshold in some sampling stations, suggesting potential adverse ecological effects. T-Hg levels in fish from both basins were lower than the WHO value $(<0.500$ $\mu \mathrm{g} / \mathrm{g}$ (wet $\mathrm{wt}$ ). The target hazard quotient values, suggest that human should minimizing meals/week of the analyzed species to avoid deleterious effect during lifetime.

Conclusions: The results suggested that mining activities significantly contribute to the considerable environmental Hg contamination in both Ankobra and Tano River basins. Therefore Hg levels should carefully monitored and controlled to reduce its inputs and mitigate potential health consequences of $\mathrm{Hg}$ accumulation in the environment.
\end{abstract}

Keywords: Ecotoxicological thresholds, Accumulation, Target hazard quotient, Total mercury, Fish

\section{Background}

Over the last decades, mercury $(\mathrm{Hg})$ is considered to be one of the environmental pollutants with the greatest impact on the biosphere and human health (Miller et al. 2011). The process by which many developing countries use elemental $\mathrm{Hg}$ to extract gold is becoming one of the primary sources of $\mathrm{Hg}$ pollution (Tomiyasu et al. 2013). In gold mining, $\mathrm{Hg}$ employed in its elemental form to produce Gold-Hg amalgams can escape to

*Correspondence: asaredonkor@yahoo.co.uk

Department of Chemistry, Kwame Nkrumah University of Science and Technology, Kumasi, Ghana the atmosphere and deposited on surrounding soils and aquatic ecosystems (Rodrigues-Filho and Maddock 1997; Cesar et al. 2011). Once it reaches the ecosystems, $\mathrm{Hg}$ is distributed into the air, soil, water, and sediments, forming the largest metal deposits in the environment (Martinez-Finley and Aschner 2014). Elemental $\mathrm{Hg}$ is highly volatile and easily dispersed at the high temperatures that often occur at sites of amalgamation and subsequently undergoes global long-range atmospheric transport and deposition that allows its accumulation in biota, with subsequent human health risks (Falandysz et al. 2014).

Moreover, leaching and soil erosion processes can also mobilize mercury to aquatic systems (Cesar et al. 2011).

\section{黛 Springer}


In the aquatic systems, $\mathrm{Hg}$ can be bio-transformed by bacteria into $\mathrm{Hg}$ and reached the top predators through its bioaccumulation and bio-magnification in the food chain (Ullrich et al. 2001). As a consequence, top predators are expected to exhibit higher mercury concentrations compared to non-carnivorous species. Besides the $\mathrm{Hg}$ vapor occupational exposure, $\mathrm{Hg}$ environmental exposure via fish consumption has become an issue of concern in areas affected by $\mathrm{Hg}$ pollution (Castilhos et al. 1998, 2006).

People living in close proximity to artisanal mining areas are vulnerable to $\mathrm{Hg}$ exposure. One of the major problems of $\mathrm{Hg}$ is its ability to cause neurotoxicity (Woods et al. 2013) and teratogenesis (Heinz et al. 2011), as well as lesions in organs such as the liver and kidneys (Sonne et al. 2013). Much of the neurotoxicity of $\mathrm{Hg}$ is associated with its ability to reach the brain by binding to cysteine, which uses the neutral amino acid transporter (Aschner and Aschner 1990).

Methyl mercury, the commonest organic mercury, can accumulate in human beings through the food chain and may give rise to both acute and chronic toxicity (Tchounwou et al. 2003; Morel et al. 1998; Harris et al. 2003; Boening 2000). Fish samples are commonly used as an indicator of Hg exposure (Dabeka et al. 2003, 2004; Thom et al. 2006; Konig et al. 2005; Virtanen et al. 2005; Wennberg et al. 2007; Yoshizawa et al. 2002; D'Itri and D'Itri 1975).

Increased use of mercury in gold recovery mining operations in many developing countries has raised concern over its release into the environment (Oppong et al. 2010). Studies on mercury contamination and health effects in the Amazon have been carried out (Pfeiffer and Larceda 1988; Larceda and Salomons 1991; Nriagu et al. 1992; Akagi and Nishimura 1991). However, in Ghana studies on assessment of mercury levels in water, sediments, soil, food crops, fish and some human tissues have been carried out in different areas (Amonoo-Neizer et al. 1996; Adimado and Baah 2002; Golow and Adzei 2002; Bannerman et al. 2003; Bonzongo et al. 2003; Babut et al. 2003; Golow and Mingle 2002; Donkor et al. 2006).

In Ghana, small-scale and artisanal gold extraction is one of the leading causes of $\mathrm{Hg}$ release to aquatic ecosystems (Ayensu 1997). Although this activity contributes significantly to rural employment in Ghana, the apparent wealth resulting from gold mining contrasts with the loss of ecosystems, as well as both health and social impairment on communities. The inappropriate use of $\mathrm{Hg}$ and the poor technical knowledge on handling and recovering have facilitated $\mathrm{Hg}$ contamination of water bodies and the atmosphere. Since artisanal gold mining activities using mercury are carried out close by the rivers, it is likely that mercury may be carried along the river.
Aquatic species like fish may be affected by this contamination and eventually affect living organisms that may also feed on these aquatic species. Therefore, the main aim of this study is to determine the extent of $\mathrm{Hg}$ pollution derived from gold mining in Ankobra and Tano River basins, as well as sediment contamination and the health risk due to $\mathrm{Hg}$ intake via fish consumption.

\section{Methods}

\section{Study area}

The Ankobra Basin is one of the south-western basins of Ghana. It is located within latitudes $4^{\circ} 52^{\prime}-6^{\circ} 27^{\prime} \mathrm{N}$, and longitudes $1^{\circ} 42^{\prime}-2^{\circ} 33^{\prime} \mathrm{W}$. It is bounded to the East; West and South by the Pra Basin, Tano Basin and the Gulf of Guinea, respectively. The basin has an area of $8403 \mathrm{~km}^{2}$ spanning 11 districts in three regions with Wassa Amenfi, Wassa West and Nzema East Districts. The basin falls under the South-Western Equatorial and the Wet Semi-Equatorial climatic regions. The South-Western Equatorial is the wettest climatic region in Ghana with mean annual rainfall above $1900 \mathrm{~mm}$. The vegetation of the basin comprises the Rain forest as well as the Moist-semi deciduous forest.

The Tano Basin is located in the southwestern part of Ghana and lies between latitudes $50^{\circ} 00^{\prime}-70^{\circ} 40^{\prime} \mathrm{N}$ and longitudes $20^{\circ} 00^{\prime}-30^{\circ} 15^{\prime} \mathrm{W}$. The southern section is generally low in altitude, ranging between 0 and $150 \mathrm{~m}$ above the mean sea level. The general topography of the entire basin, however, ranges between 0 and $700 \mathrm{~m}$ above the mean sea level. The climate of the Tano Basin falls partly under the wet semi-equatorial and partly under south-western equatorial climatic zones of Ghana. It is thus characterized by double rainfall maxima. The Tano basin traverses three administrative regions: The Brong Ahafo, Ashanti, and Western Regions, comprising 21 administrative districts. There is commercial farming of cocoa, plantain, and other commercial and food crops. Only about $10 \%$ of the landmass is used for human settlement. The forest cover represents the second highest land use pattern in the basin and follows closely after agricultural lands, occupying about $50 \%$ of the total landmass of the basin. The remaining $40 \%$ of the landmass is covered by forests which are largely protected areas. The Tano basin has its source within the forest in Pooyem, $4 \mathrm{~km}$ from Techiman, and flows roughly north-south into the sea. The basin enters the sea outside Ghana, in the Cote d'Ivoire. The main tributaries of the Tano River system are the Abu, Amama, Bo, Disue, Soro, Atronie, Sabom, Gaw, Kwasa, Sumre, and Totua. The Tano River System has a total catchment area of about $15,000 \mathrm{Km}^{2}$ shared between Ghana and Cote D'Ivoire. The Tano River Basin constitutes a major source of domestic water supply from surface and groundwater. 


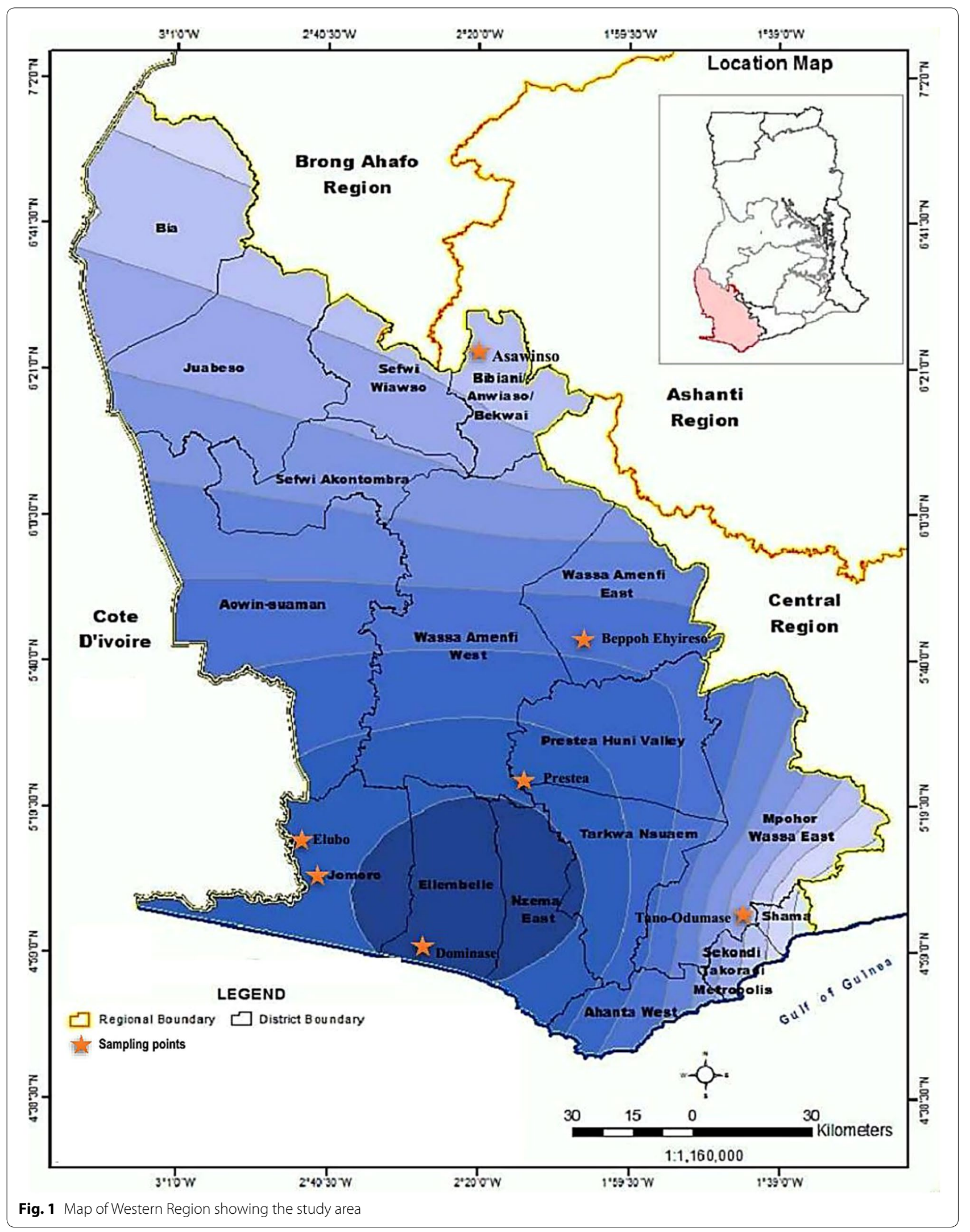




\section{Sampling locations}

Sampling locations were carefully selected along the courses of Ankobra and Tano river (Fig. 1). These locations include Asawinso, Beppoh Ehyireso, HemanPrestea and Dominase all along the Ankobra River, and Tano-Odumase, Jomoro and Elubo, all along the Tano River. Samples were also taken from Bonsaso and Asuo Kofi River, which are tributaries of the Ankobra River.

\section{Sample collection}

Sampling was done during two periods in April/May 2014 (on-set of rainy season) and November/December 2014 (on-set of dry season) from the various locations indicated above. Depth integrated water samples were collected over bridges and preserved at about $\mathrm{pH} 2$ with conc. $\mathrm{HNO}_{3}$, whilst sediment samples were collected through coring with a PVC tube. Two water and sediment samples were taken from each location. The fish samples were collected using dragnet and stored in an ice chest at $4{ }^{\circ} \mathrm{C}$ and transported to the laboratory. The samples were later identified in the laboratory and prepared for analysis.

\section{Sample preparation}

The water samples from each location were bulked and filtered through a Whatman No 41 filter paper prior to digestion. The sediment samples from each location were also bulked and dried in an oven at $60{ }^{\circ} \mathrm{C}$ to a constant weight. The dried samples were then pulverized and sieved through $20 \mathrm{~mm}$-mesh size. Separate aliquots parts of the fish samples were weighed and dried in an oven at $105^{\circ} \mathrm{C}$ to a constant weight.

\section{$\mathrm{Hg}$ in water}

$5 \mathrm{~mL}$ concentrated $\mathrm{H}_{2} \mathrm{SO}_{4}$ was added to $50 \mathrm{~mL}$ of three representative aliquots from the bulked water sample in $100 \mathrm{~mL}$ volumetric flask followed by $2.5 \mathrm{~mL}$ concentrated $\mathrm{HNO}_{3}$ and then $15 \mathrm{~mL}$ of $5 \% \mathrm{KMnO}_{4}$. The mixture was allowed to stand for at least $15 \mathrm{~min}, 8 \mathrm{~mL}$ of $5 \% \mathrm{~K}_{2} \mathrm{~S}_{2} \mathrm{O}_{8}$ solution was added and then heated in a water bath at $95{ }^{\circ} \mathrm{C}$. The sample was allowed to cool to room temperature after which $10 \% \mathrm{HONH}_{3} \mathrm{Cl}$ was added to reduce excess $\mathrm{KMnO}_{4}$ and then diluted with double distilled water (Greenberg et al. 1992; Perkin Elmer 1994).

\section{$\mathrm{Hg}$ in sediment}

About $2 \pm 0.05 \mathrm{~g}$ of three representative aliquot from the bulk of dry, finely ground and sieved sample was weighed into a $250 \mathrm{~mL}$ beaker follow by the addition of $25 \mathrm{~mL}$ concentrated $\mathrm{H}_{2} \mathrm{SO}_{4}$. A $1 \mathrm{~mL}$ additions of $50 \% \mathrm{H}_{2} \mathrm{O}_{2}$ was carefully added, allowing sufficient time for decomposition of the peroxide. The sample was heated gently on a sand bath to decompose any sediment and then sufficient amount of $5 \% \mathrm{KMnO}_{4}$ was added to the solution in order to maintain a permanent pink color. After cooling to room temperature, the excess $\mathrm{KMnO}_{4}$ was reduced by addition of sufficient amount of $10 \% \mathrm{HONH}_{3} \mathrm{Cl}$ solution (Larry et al. 1991). The resultant solution was then filtered into a $250 \mathrm{~mL}$ volumetric flask and made to mark with distilled water.

\section{$\mathrm{Hg}$ in fish}

Samples of fish tissue were cut into small pieces on a plastic cutting board using a stainless-steel knife. Four representative aliquots were sampled by halving and quartering prior to weighing. About $0.5 \pm 0.05 \mathrm{~g}$ of each aliquot was weighed into a $100 \mathrm{~mL}$ beaker and $4 \mathrm{~mL}$ concentrated $\mathrm{H}_{2} \mathrm{SO}_{4}$ was added followed by1 $\mathrm{mL}$ concentrated $\mathrm{HNO}_{3}$ and then placed in a water bath maintained at $58{ }^{\circ} \mathrm{C}$ until the tissue completely dissolved. The sample was then cooled to $4{ }^{\circ} \mathrm{C}$ in an ice bath and $5 \mathrm{~mL}$ of $5 \% \mathrm{KMnO}_{4}$ in $1 \mathrm{~mL}$ increments was cautiously added. About $8 \mathrm{~mL}$ of $5 \% \mathrm{~K}_{2} \mathrm{~S}_{2} \mathrm{O}_{8}$ was then added and allowed to stand overnight at room temperature. Excess amount of $\mathrm{KMnO}_{4}$ was reduced by addition of sufficient amount of $10 \% \mathrm{HONH}_{3} \mathrm{Cl}$ and then transferred quantitatively into a $100 \mathrm{~mL}$ volumetric flask and dilute to the mark.

Reagent blanks were prepared for each batch of sample and standard using equal amounts of all reagents used in the sample or standard preparation. The reagent blanks were used to correct for background absorption due to the reagent.

\section{Analytical quality control}

The quality assurance and control aspects of the analysis were implemented through the analytical protocols, including sampling and sample preservation, instrument performance evaluation, instrument calibration, recovery and reagent blank analyses. The instrument performance evaluation involved optimizing instrument parameters followed by sensitivity check. The measured average characteristic concentration was $0.146 \mathrm{ng} / 0.0044$ A with a confidence interval of $0.146 \pm 0.004(n=5)$ at the $95 \%$ confidence level as against the instrument manufacturers specification of $0.138 \mathrm{ng} / 0.0044 \mathrm{~A}$. The optimized instrument parameters were maintained throughout the analyses, and the average percent recoveries for $\mathrm{Hg}$ was recorded as $0.098 \pm 0.001(n=5)$.

\section{Calibration of instrument}

The instrument was calibrated using a standard solutions of $\mathrm{Hg}$ prior to the analyses of samples. $\mathrm{Hg}$ calibration and recovery standards were prepared by dissolving $0.1354 \mathrm{~g}$ of $\mathrm{HgCl}_{2}$ (Analar Grade) with about $70 \mathrm{~mL}$ double distilled water and concentrated $\mathrm{HNO}_{3}$. The solution was transferred into a $100 \mathrm{~mL}$ volumetric flask and made up 
to the mark with distilled water. A $1 \mathrm{~mL}$ of the resulting solution of concentration $1.0 \mathrm{mg} / \mathrm{mL} \mathrm{Hg}$ was transferred into a $1 \mathrm{~L}$ volumetric flask and treated with concentrated $\mathrm{H}_{2} \mathrm{SO}_{4}, 5 \% \mathrm{~K}_{2} \mathrm{~S}_{2} \mathrm{O}_{8}$ and $10 \% \mathrm{HONH}_{3} \mathrm{Cl}$, and made up to the mark with double distilled water. The resulting solution of concentration $1000 \mu \mathrm{g} / \mathrm{L}$ was diluted serially to obtain other solutions of lower concentrations.

\section{Sample analyses}

All samples were analyzed in triplicates using the cold vapor technique with Perkin-Elmer 5100PC AAS equipped with a flow injection analysis system (FIAS, AS-90). A mixture $3 \% \mathrm{HCl}$ and $1.1 \% \mathrm{SnCl}_{2}$ in $3 \% \mathrm{HCl}$ was used as a carrier solution and reducing agent respectively.

\section{Assessment of sediment contamination}

The geochemical accumulation index $\left(\mathrm{I}_{\text {geo }}\right)$ was employed as a quantitative tool to assess the level of $\mathrm{Hg}$ contamination in sediments. This index was calculated using Eq. (1) proposed by Müller (1969):

$$
\mathrm{I}_{\text {geo }}=\log _{2} \frac{C_{n}}{1.5 \times B_{n}}
$$

where $C_{n}$ is the sediment metal concentration; $A$ is the constant for modifying the fluctuation of the background value caused by lithological movement, usually 1.5 (Bhuiyan et al. 2010); and $B_{n}$ is the geochemical background value of the metal. In this work, two reported background values were utilized: 0.06 (Lecce and Pavlowsky 2014) and $0.08 \mu \mathrm{g} / \mathrm{g}$ (Hortellani et al. 2013). Based on the results, $\mathrm{Hg}$ pollution in the sediment was classified into seven different categories: class 0 (unpolluted), $\mathrm{I}_{\text {geo }} \leq 0$; class 1 (unpolluted to moderately polluted), $0 \leq \mathrm{I}_{\text {geo }} \leq 1$; class 2 (moderately polluted), $1 \leq \mathrm{I}_{\text {geo }} \leq 2$; class 3 (moderately to strongly polluted), $2 \leq \mathrm{I}_{\text {geo }} \leq 3$; class 4 (strongly polluted), $3 \leq \mathrm{I}_{\text {geo }} \leq 4$; class 5 (strongly to extremely polluted), $4 \leq \mathrm{I}_{\text {geo }} \leq 5$; and class 6 (extremely contaminated), $I_{\text {geo }}>5$ (Müller 1969).

\section{Risk-based consumption limits}

Risk factors were calculated according to the guidelines of the US Environmental Protection Agency (US-EPA 1989, 2000), previously reported by (Marrugo-Negrete et al. 2008; Copat et al. 2013a, b). It was assumed that the ingestion dose was equal to the adsorbed $\mathrm{Hg}$ dose (Chien et al. 2002). Hg consumption limit calculations were based on the reference dose $\left(\operatorname{RfD}_{0}\right)$ set by the US-EPA. Target hazard quotient (THQ), indicate the ratio between exposure and the reference dose, and calculations were made using the standard assumption for an integrate USEPA risk analysis. The estimated daily intake per meal $\left(E_{\mathrm{m}}\right)$ and for the target hazard quotient (THQ) were calculated using Eqs. (2) and (3), respectively reported by (Copat et al. 2013a, b,):

$$
\begin{aligned}
& \mathrm{EDI}_{\mathrm{m}}=\frac{\mathrm{MS} \times \mathrm{C}}{\mathrm{BW}} \\
& \mathrm{THQ}=\frac{\mathrm{EDI}_{\mathrm{m}}}{\mathrm{RfD}}
\end{aligned}
$$

where $\mathrm{EDI}_{\mathrm{m}}$ is the estimated daily intake of $\mathrm{Hg}$ per meal size; MS is the standard portion size of $230 \mathrm{~g}$ for adults (Hosseini et al. 2013); C is the Hg concentration (mg/ kg w.w.) (Marrugo-Negrete et al. 2008); BW is the body weight of $70 \mathrm{~kg}$ for adults (Copat et al. 2013a). According to US-EPA (1989), when THQ risk is above 1, systemic effects may occur. RfD for T-Hg is $0.1 \mu \mathrm{g} / \mathrm{g} /$ day.

The allowable number of fish meals of a specific meal size that may be consumed over a given period of time was also evaluated. For noncarcinogenic effects, maximum allowable fish consumption rate in meals/week $\left(\mathrm{CR}_{\mathrm{mw}}\right)$ (US-EPA 2000) that would not be expected to cause any chronic systemic effects was obtained using Eq. (4):

$$
\mathrm{Cr}_{\mathrm{mw}}=\frac{49}{\mathrm{C} \times \mathrm{MS}}
$$

Considering an average adult body weight of $70 \mathrm{~kg}$ (USEPA 1994), the Hg USEPA Acceptable Daily Intake (ADI) can be approximated as $7 \mu \mathrm{g} /$ day/adult $(49 \mu \mathrm{g} \mathrm{Hg} /$ week) (Hosseini et al. 2013).

\section{Statistical analysis}

Data for $\mathrm{Hg}$ analysis are presented as mean \pm standard deviation. Correlation or multiple linear regression analysis was used to establish relationships between the two variables. For all purposes, significance was set at $\mathrm{p}<0.05$. Statistical analysis was carried out using both Microsoft Excel (2016 edition) and statistical Package for Social Science (IBM SPSS version 20) software.

\section{Results and discussion}

\section{Mercury in sediments and geoaccumulation analysis}

Levels of T-Hg in sediment samples revealed high variability (Table 1). Hg recorded the maximum mean value of $73.31 \mu \mathrm{g} / \mathrm{g}$ at Heman Prestea and the minimum mean value of $23.39 \mu \mathrm{g} / \mathrm{g}$ at Beppoh Ehyireso in the Ankobra River basin. Significant levels have also been detected in other areas such as Dominase, with a mean value of $66.30 \mu \mathrm{g} / \mathrm{g}$, downstream of Asuo Kofi (Table 1). The overall mean value of $\mathrm{Hg}$ in sediment from the Ankobra River basin was found to be $43.12 \mu \mathrm{g} / \mathrm{g}$ with a \%RSD of 56.9. In the Tano River basin, the concentration of $\mathrm{Hg}$ in sediment ranged from 14.43 to $21.51 \mu \mathrm{g} / \mathrm{g}$ with an overall 
Table $1 \mathrm{Hg}$ concentrations in sediment $(\mu \mathrm{g} / \mathrm{g})$ collected from the Ankobra and Tano River Basins

\begin{tabular}{lllll}
\hline \multicolumn{1}{c}{ Site } & $\mathbf{H g}(\boldsymbol{\mu g} \mathbf{g} \mathbf{g})$ & $\mathbf{I}_{\mathbf{g e o}}$ & Sediment quality \\
\hline Ankobra & Asawinso & $27.76 \pm 8.55$ & 8.27 & Extremely contaminated \\
Basin & Beppoh Ehyireso & $23.39 \pm 7.05$ & 8.02 & Extremely contaminated \\
& Heman Prestea & $73.31 \pm 55.60$ & 9.67 & Extremely contaminated \\
& Dominase & $66.30 \pm 51.51$ & 9.52 & Extremely contaminated \\
& Bonsaso & $24.82 \pm 9.94$ & 8.11 & Extremely contaminated \\
Tano & Tano Odumasi & $14.43 \pm 4.47$ & 7.32 Extremely contaminated \\
Basin & Jomoro & $16.18 \pm 4.08$ & 7.49 & Extremely contaminated \\
& Elubo & $21.51 \pm 0.24$ & 7.90 Extremely contaminated \\
\hline
\end{tabular}

mean value of $17.37 \mu \mathrm{g} / \mathrm{g}$ with $21.2 \% \mathrm{RSD}$. T-Hg concentrations were greater than those reported for Mina Santa Cruz Marsh (gold-mining site), Colombia [0.140$0.355 \mu \mathrm{g} / \mathrm{g} \mathrm{dw}$ (Olivero and Solano 1998)] and village of Caimito, San Jorge River basin $[0.155 \pm 0.016 \mu \mathrm{g} / \mathrm{g} \mathrm{dw}$ (Olivero et al. 2004)]. On the other hand, considering a $\mathrm{Hg}$ threshold of $0.2 \mu \mathrm{g} / \mathrm{g}$ as the level of concern for $\mathrm{Hg}$ in continental water sediments (Salomons and Förstner 1984), on average, both basins may be categorized as highly polluted.

Based on sediment $\mathrm{T}-\mathrm{Hg}$ levels, sampling sites representing the two basins have significant differences between them ( $p>0.05$ ). Heman Prestea, has the highest concentrations, and it receives a direct impact from gold mining along the Ankobra River, where Hg used during gold amalgamation reaches the river together with washed sediments.

The $I_{\text {geo }}$ data for the sampling sites are presented in Table 1. The Mullers geochemical index $\left(\mathrm{I}_{\text {geo }}\right)$ values ranged from 8.02-9.67 and 7.32-7.90 for both Ankobra and Tano River basin, respectively. According to the $\mathrm{I}_{\text {geo }}$ indexes, $\mathrm{Hg}$ pollution in these sediments classifies them as highly to strongly polluted (class 6), comparable to sediments found in an abandoned gold mining area in southern Minas Gerais State, Brazil (Cesar et al. 2011) and the Middle Odra River (Germany/Poland) (Boszke et al. 2004). These concentrations are far from the allowable limit of $0.81 \mu \mathrm{g} / \mathrm{g}$ suggested by the International Atomic Energy Agency (IAEA) (Kwaansa-Ansah et al. 2011).

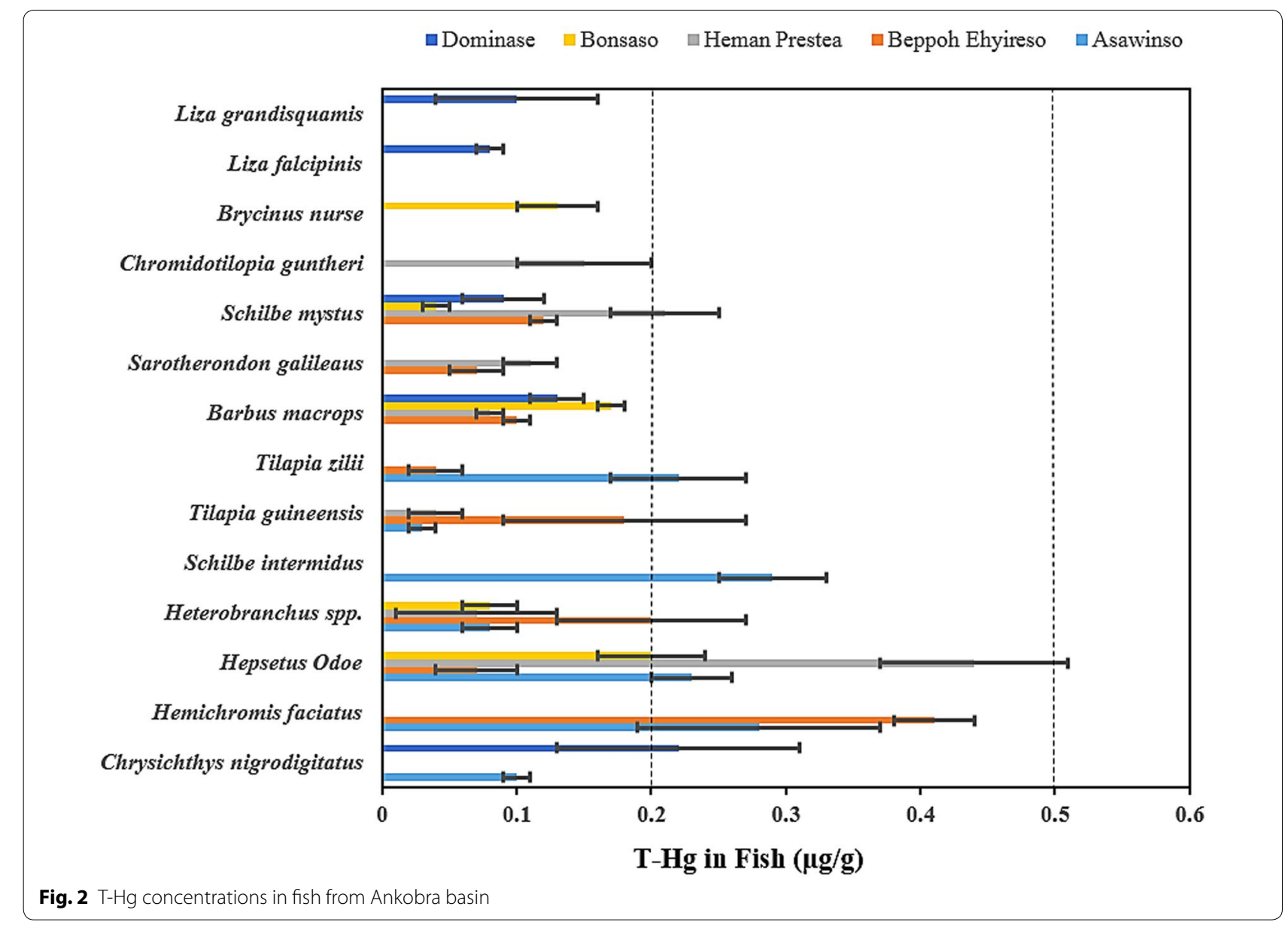




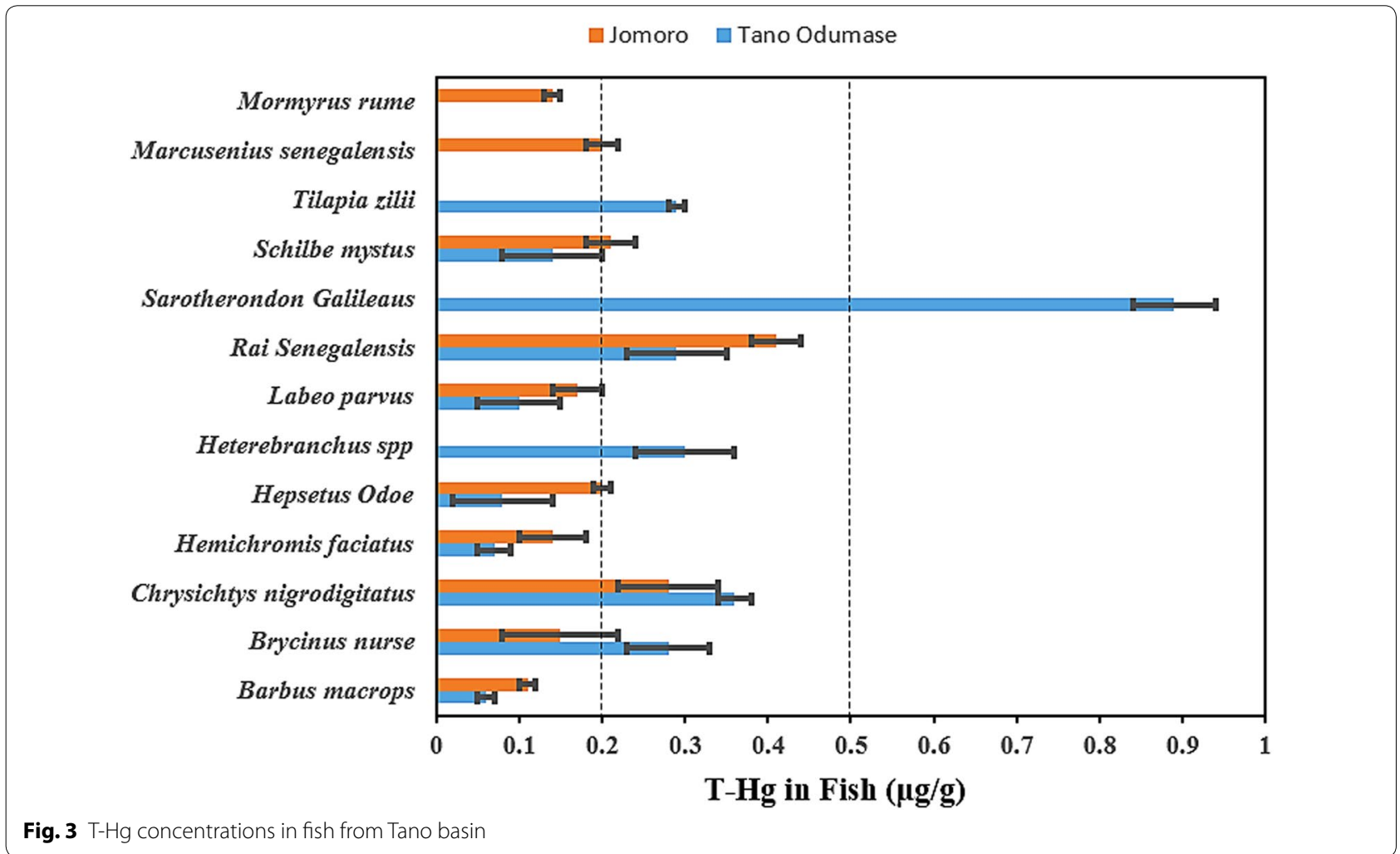

\section{Mercury in Fish from the Ankobra and Tano River basins}

The average muscle $\mathrm{T}-\mathrm{Hg}$ concentrations in fish are depicted in Figs. 2 and 3. The Ankobra River basin measured levels of $\mathrm{T}-\mathrm{Hg}$ in the range of $0.03-0.443 \mu \mathrm{g} / \mathrm{g}$ (wet $\mathrm{wt}$ ), whereas Tano River basin measured $\mathrm{T}-\mathrm{Hg}$ concentration in the range of $0.068-0.413 \mu \mathrm{g} / \mathrm{g}$ (wet wt). The highest $\mathrm{T}-\mathrm{Hg}$ concentrations were observed in Tano Odumase, (Sarotherodon Galilaeus, $0.89 \pm 0.05 \mu \mathrm{g} / \mathrm{g}$ ). In Tano Basin, Tilapia guineensis recorded lower T-Hg levels of $0.03 \pm 0.01 \mu \mathrm{g} / \mathrm{g}$. The overall mean $\mathrm{T}-\mathrm{Hg}$ concentration was found to be $<0.5 \mu \mathrm{g} / \mathrm{g}$ fresh $\mathrm{wt}$, the maximum $\mathrm{T}-\mathrm{Hg}$ concentration that should be present in fish for human consumption according to JOINT FAO/WHO (2010), except Sarotherondon Galilaeus.

To protect vulnerable people, in particular, pregnant women, those under 15 years of age, and frequent fish consumers, the WHO (1990) has recommended the lower T-Hg guideline of $0.2 \mu \mathrm{g} / \mathrm{g}$ fresh wt for those groups. T-Hg concentrations found in most fish species were higher than $0.2 \mu \mathrm{g} / \mathrm{g}$.

\section{Risk-based consumption limits}

Estimated $\mathrm{EDI}_{\mathrm{m}}, \mathrm{THQ}$, and $\mathrm{CR}_{\mathrm{mw}}$ values are presented in Table 2. Values of estimated daily intake per meal size of seafood for humans in some species were higher than the accepted tolerable intake provided by Joint FAO/WHO
Expert Committee on Food Additive (JECFA 2010), suggesting that levels of assumed exposure are likely to cause deleterious effect during lifetime in humans. The specific consumption limits obtained, confirming THQ values above 1 , indicate that it would be appropriate to minimize the weekly meals of the analyzed fish species, to avoid the chronic systemic effects due to $\mathrm{Hg}$ content. Special concern are Hemichromis fasciatus, Schilbe intermedius, Hepsetus Odoe, Rai Senegalensis, Sarotherodon Tilapia zillii, Galilaeus Brycinus nurse, Heterobranchus spp, Chrysichthys nigrodigitatus and Chrysichthys nigrodigitatus species. All the $\mathrm{CR}_{\mathrm{mw}}$ values were $>14$ meals/week. Tano basin showed the lowest level of fish meals suggested. $\mathrm{EDI}_{\mathrm{m}}, \mathrm{THQ}$, and $\mathrm{CR}_{\mathrm{mw}}$ results, indicates that the species that can be eaten with low risk for human health are Tilapia guineensis, Barbus macrops, Schilbe mystus, Chromidotilopia guntheri, Liza grandisquamis, Labeo parvus, and Mormyrus rume.

\section{Mercury in water}

The levels of $\mathrm{Hg}$ in water samples from both the Ankobra and Tano River Basins are shown in Table 3. The maximum mean $\mathrm{Hg}$ value of $1.078 \mu \mathrm{g} / \mathrm{L}$ was recorded at Asuo Kofi, a tributary to the Ankobra River, whilst the minimum mean value of $0.145 \mu \mathrm{g} / \mathrm{L}$ was measured at Dominase, located downstream of the Ankobra River. The 
Table 2 Estimated daily intake per meal $\left(E D I_{m}\right)$ ( $\mu g / g$ daily), target hazard quotient (THQ), and maximum allowable fish consumption rate in meals/week $\left(\mathrm{CR}_{\mathrm{mw}}\right)$ in adults

\begin{tabular}{|c|c|c|c|c|c|}
\hline Sampling sites & Fish species & $\begin{array}{l}\mathrm{T}-\mathrm{Hg}(\mu \mathrm{g} / \mathrm{g}) \\
\text { Mean } \pm \text { SD }\end{array}$ & $\mathrm{EDI}_{\mathrm{m}}$ & THQ & $\mathrm{CR}_{\mathrm{mw}}$ \\
\hline \multicolumn{6}{|l|}{ Ankobra basin } \\
\hline \multirow[t]{7}{*}{ Asawinso } & Tilapia zillii & $0.22 \pm 0.05$ & 0.79 & 7.86 & 1 \\
\hline & Tilapia guineensis & $0.03 \pm 0.01$ & 0.11 & 1.07 & 7 \\
\hline & Hepsetus Odoe & $0.23 \pm 0.03$ & 0.82 & 8.21 & 1 \\
\hline & Hemichromis fasciatus & $0.28 \pm 0.09$ & 1.00 & 10.00 & 1 \\
\hline & Schilbe intermedius & $0.29 \pm 0.04$ & 1.04 & 10.36 & 1 \\
\hline & Heterobranchus spp. & $0.08 \pm 0.02$ & 0.29 & 2.86 & 3 \\
\hline & Chrysichthys nigrodigitatus & $0.10 \pm 0.01$ & 0.36 & 3.57 & 2 \\
\hline \multirow[t]{8}{*}{ Beppoh Ehyireso } & Tilapia zillii & $0.04 \pm 0.02$ & 0.14 & 1.43 & 5 \\
\hline & Hemichromis fasciatus & $0.41 \pm 0.03$ & 1.46 & 14.64 & 1 \\
\hline & Tilapia guineensis & $0.18 \pm 0.09$ & 0.64 & 6.43 & 1 \\
\hline & Heterobranchus spp & $0.20 \pm 0.07$ & 0.71 & 7.14 & 1 \\
\hline & Sarotherodon galilaeus & $0.07 \pm 0.02$ & 0.25 & 2.50 & 3 \\
\hline & Barbus macrops & $0.10 \pm 0.01$ & 0.36 & 3.57 & 2 \\
\hline & Schilbe mystus & $0.12 \pm 0.01$ & 0.43 & 4.29 & 2 \\
\hline & Hepsetus Odoe & $0.07 \pm 0.03$ & 0.25 & 2.50 & 3 \\
\hline \multirow[t]{7}{*}{ Heman prestea } & Hepsetus Odoe & $0.44 \pm 0.07$ & 1.57 & 15.71 & 0 \\
\hline & Tilapia guineensis & $0.04 \pm 0.06$ & 0.14 & 1.43 & 5 \\
\hline & Barbus macrops & $0.08 \pm 0.01$ & 0.29 & 2.86 & 3 \\
\hline & Sarotherodon galilaeus & $0.11 \pm 0.02$ & 0.39 & 3.93 & 2 \\
\hline & Chromidotilopia guntheri & $0.15 \pm 0.05$ & 0.54 & 5.36 & 1 \\
\hline & Heterobranchus spp & $0.07 \pm 0.06$ & 0.25 & 2.50 & 3 \\
\hline & Schilbe mystus & $0.21 \pm 0.04$ & 0.75 & 7.50 & 1 \\
\hline \multirow[t]{5}{*}{ Bonsaso } & Schilbe mystus & $0.04 \pm 0.01$ & 0.14 & 1.43 & 5 \\
\hline & Brycinus nurse & $0.13 \pm 0.03$ & 0.46 & 4.64 & 2 \\
\hline & Hepsetus Odoe & $0.20 \pm 0.04$ & 0.71 & 7.14 & 1 \\
\hline & Barbus macrops & $0.17 \pm 0.01$ & 0.61 & 6.07 & 1 \\
\hline & Heterobranchus spp & $0.08 \pm 0.02$ & 0.29 & 2.86 & 3 \\
\hline \multirow[t]{5}{*}{ Dominase } & schilbe mystus & $0.09 \pm 0.03$ & 0.32 & 3.21 & 2 \\
\hline & Barbus macrops & $0.13 \pm 0.02$ & 0.46 & 4.64 & 2 \\
\hline & Liza falcipinnis & $0.08 \pm 0.01$ & 0.29 & 2.86 & 3 \\
\hline & Chrysichthys nigrodigitatus & $0.22 \pm 0.09$ & 0.79 & 7.86 & 1 \\
\hline & Liza grandisquamis & $0.10 \pm 0.06$ & 0.36 & 3.57 & 2 \\
\hline \multicolumn{6}{|l|}{ Tano basin } \\
\hline \multirow[t]{11}{*}{ Tano odumase } & RaiSenegalensis & $0.29 \pm 0.06$ & 1.04 & 10.36 & 1 \\
\hline & Labeo parvus & $0.10 \pm 0.05$ & 0.36 & 3.57 & 2 \\
\hline & Sarotherodon Galilaeus & $0.89 \pm 0.05$ & 3.18 & 31.79 & 0 \\
\hline & Barbus macrops & $0.06 \pm 0.01$ & 0.21 & 2.14 & 4 \\
\hline & Hemichromis fasciatus & $0.07 \pm 0.02$ & 0.25 & 2.50 & 3 \\
\hline & Brycinus nurse & $0.28 \pm 0.05$ & 1.00 & 10.00 & 1 \\
\hline & Schilbe mystus & $0.14 \pm 0.06$ & 0.50 & 5.00 & 2 \\
\hline & Heterobranchus spp & $0.30 \pm 0.06$ & 1.07 & 10.71 & 1 \\
\hline & Chrysichthys nigrodigitatus & $0.36 \pm 0.02$ & 1.29 & 12.86 & 1 \\
\hline & Tilapia zillii & $0.29 \pm 0.01$ & 1.04 & 10.36 & 1 \\
\hline & Hepsetus Odoe & $0.08 \pm 0.06$ & 0.29 & 2.86 & 3 \\
\hline
\end{tabular}


Table 2 continued

\begin{tabular}{|c|c|c|c|c|c|}
\hline Sampling sites & Fish species & $\begin{array}{l}\mathrm{T}-\mathrm{Hg}(\mu \mathrm{g} / \mathrm{g}) \\
\text { Mean } \pm \mathrm{SD}\end{array}$ & $\mathrm{EDI}_{\mathrm{m}}$ & THQ & $\mathrm{CR}_{\mathrm{mw}}$ \\
\hline \multirow[t]{10}{*}{ Jomoro } & Chrysichthys nigrodigitatus & $0.28 \pm 0.06$ & 1.00 & 10.00 & 1 \\
\hline & Raisenegalensis & $0.41 \pm 0.03$ & 1.46 & 14.64 & 1 \\
\hline & Hepsetus Odoe & $0.20 \pm 0.01$ & 0.71 & 7.14 & 1 \\
\hline & Marcusenius senegalensis & $0.20 \pm 0.02$ & 0.71 & 7.14 & 1 \\
\hline & Schilbe mystus & $0.21 \pm 0.03$ & 0.75 & 7.50 & 1 \\
\hline & Mormyrus rume & $0.14 \pm 0.01$ & 0.50 & 5.00 & 2 \\
\hline & Barbus macrops & $0.11 \pm 0.01$ & 0.39 & 3.93 & 2 \\
\hline & Hemichromis fasciatus & $0.14 \pm 0.04$ & 0.50 & 5.00 & 2 \\
\hline & Labeo parvus & $0.17 \pm 0.03$ & 0.61 & 6.07 & 1 \\
\hline & Brycinus nurse & $0.15 \pm 0.07$ & 0.54 & 5.36 & 1 \\
\hline
\end{tabular}

Table 3 Mean concentrations of $\mathrm{Hg}$ in water from Ankobra and Tano basin $(n=6)$

\begin{tabular}{lllll}
\hline & $\begin{array}{l}\text { Sampling } \\
\text { location }\end{array}$ & pH & TDS $(\mathbf{m g} / \mathbf{L})$ & $\begin{array}{l}\mathbf{H g}(\boldsymbol{\mu g} / \mathbf{L}) \\
\text { Mean } \pm \text { SD }\end{array}$ \\
\hline Ankobra basin & Asawinso & 7.30 & 42.5 & $0.320 \pm 0.101$ \\
& Beppoh Ehyireso & 7.64 & 14.0 & $0.282 \pm 0.090$ \\
& Heman Prestea & 6.90 & 15.0 & $0.264 \pm 0.022$ \\
& Asuo Kofi & 8.00 & 203.5 & $1.078 \pm 0.940$ \\
& Dominase & 7.27 & 14.0 & $0.145 \pm 0.061$ \\
& Bonsaso & 7.45 & 14.0 & $0.184 \pm 0.111$ \\
Tano basin & Tano Odumase & 7.48 & 58.8 & $0.216 \pm 0.091$ \\
& Jomoro & 8.12 & 37.1 & $0.250 \pm 0.110$ \\
& Elubo & 7.35 & 17.0 & $0.214 \pm 0.080$ \\
\hline
\end{tabular}

mean level of $\mathrm{Hg}$ in the entire Ankobra River basin is $0.348 \mu \mathrm{g} / \mathrm{L}$ with a root square deviation (RSD) of $94.0 \%$. The maximum mean concentration of $\mathrm{Hg}$ in the Tano River basin was found to be $0.250 \mu \mathrm{g} / \mathrm{L}$ at Jomoro whilst the minimum mean value of $0.214 \mu \mathrm{g} / \mathrm{L}$ was recorded at Elubo. The maximum concentration of were below the WHO guideline value of $1.00 \mu \mathrm{g} / \mathrm{L}$ for drinking water (WHO 1985). The corresponding mean value for the entire Tano River basin is $0.227 \mu \mathrm{g} / \mathrm{L}$. Comparing the overall mean values for the two River basins, the Ankobra River basin is being impacted more with $\mathrm{Hg}$ pollution than the Tano River basin.

It is quite apparent that in areas of high discharges of trace metals usually associated with mining activities, these metals do not occur in very high concentrations in surface waters. The $\mathrm{pH}$ range of $6.0-8.0$ as observed for water from both the Ankobra and Tano River basin and in the presence of suspended solids, adsorption and co-precipitation processes can remove metals such as $\mathrm{Hg}$ from solutions as sulfides under anoxic conditions (Hamilton 1971). This may account for the observed low concentrations of $\mathrm{Hg}$ in water from both River basins as compared to the very high $\mathrm{Hg}$ concentrations in sediments (Table 1). Water T-Hg values found in this study are lower than those reported for other rivers contaminated with artisanal gold mining in Ghana [162-164 ng/L (Donkor et al. 2006)], Indonesia [up to $250 \mathrm{ng} / \mathrm{L}$ (Limbong et al. 2005)] and Brazil [up to $800 \mathrm{ng} / \mathrm{L}$ (Palheta and Taylor 1995)].

\section{Conclusions}

The study revealed considerable $\mathrm{Hg}$ contamination in sediment, water and fish collected from the Ankobra and Tano River basins which drain the major gold mining areas in Ghana. Human T-Hg concentrations together with the THQ data indicates more extensive and intensive ecological and environmental health studies in the region by the local government. Although fish are considered the main source of $\mathrm{Hg}$ exposure, they are the only source of protein from the daily food intake of many populations in this region. In addition, it should be pointed out that, besides fish eaters, miners are exposed to $\mathrm{Hg}$ but in its inorganic form, and this could also end up in severe health problems. However, since $\mathrm{Hg}$ like any other heavy metal undergo bioaccumulation and bio magnification, the levels should be carefully monitored and controlled to minimize inputs of $\mathrm{Hg}$ into the environment to mitigate the potential health risk associated with $\mathrm{Hg}$ exposure through fish consumption.

\section{Abbreviations}

AAS: atomic absorption spectrophotometer; CF: contamination factor; I geo: geochemical index; RSD: relative standard deviation; FIAS: flow injection analysis system; BW: body weight; EPA: Environmental Protection Agency; WHO World Health Organization; FAO: Food and Agricultural Organization; THQ: target hazard quotient; $E D I_{m}$ : estimated daily intake per meal; $\mathrm{CR}_{\mathrm{mw}}$ : consumption rate in meal/weak.

\section{Authors' contributions}

All authors read and approved the final manuscript. 


\section{Acknowledgements}

The authors gratefully acknowledge Dr. Kofi Abban of the Fisheries Biology Department of the Water research Institute, CSIR, for identifying the fish species.

\section{Competing interests}

The authors declare that they have no competing interests.

Received: 13 October 2015 Accepted: 12 January 2016

Published online: 01 February 2016

\section{References}

Adimado AA, Baah DA (2002) Mercury in human blood, urine, hair, nail and fish from the Ankobra and Tano river Basin in South Western Ghana. Bull Environ Contam Toxicol 68:339-346

Akagi H, Nishimura H (1991) Speciation of mercury in the environment. In: Suzuki T, Imura N, Clarkson TW (eds) Advances in mercury toxicology. Plenum Press, New York, pp 53-76

Amonoo-Neizer EH, Nyamah D, Bakiamoh SB (1996) Mercury and arsenic pollution in soil and biological samples around the mining towns of Obuasi, Ghana. Water Air Soil Pollut 91:363-373

Aschner M, Aschner JL (1990) Mercury neurotoxicity: mechanisms of blood-brain barrier transport. Neurosci Biobehav Rev 14(2):169-176. doi:10.1016/S0149-7634(05)80217-9

Ayensu EA (1997) Ashanti Gold, Marshad Edition Development Ltd, p 90-92

Babut M, Sekyi R, Rambaud A (2003) Improving the environmental management of small scale gold mining in Ghana: a case study of Dumasi. J Cleaner Prod 11:215-221

Bannerman W, Potin-Gautier M, Amouroux D, Tellier S, Rambaud A, Babut M, Adimado A, Beinhoff C (2003) Mercury and arsenic in the gold mining regions of the Ankobra river basin in Ghana. J Phys IV 107:107-110

Bhuiyan MA, Parvez L, Islam M, Dampare SB, Suzuki S (2010) Heavy metal pollution of coal mine-affected agricultural soils in the northern part of Bangladesh. J Hazard Mater 173(1):384-392. doi:10.1016/j. jhazmat.2009.08.085

Boening DW (2000) Ecological effects, transport, and fate of mercury: a general review. Chemosphere 40(12):1335-1351

Bonzongo JC, Donkor AK, Nartey VK (2003) Environmental impacts of mercury related to artisanal gold mining in Ghana. J Phy IV 107:217-220

Boszke L, Sobczynski T, Glosinska G, Kowalski A, Siepak J (2004) Distribution of mercury and other heavy metals in bottom sediments of the Middle Odra River (Germany/Poland). Pol J Environ Stud 13(5):495-502

Castilhos ZC, Bidone ED, Lacerda LD (1998) Increase of the reference human exposure to mercury through fish consumption due to gold mining at the Tapajos river region, Amazon. Bull Environ Cont Toxicol 6:202-209. doi:10.1007/s001289900749

Castilhos ZC, Rodrigues-Filho S, Rodrigues APC, Viilas-Bôas RCV, Siegel S, Veiga M, Beinhoff C (2006) Mercury contamination in fish from gold mining areas in Indonesia and human health risk assessment. Sci Total Environ 368:320-325. doi:10.1016/j.scitotenv.2006.01.039

Cesar R, Egler S, Polivanov H, Castilhos Z, Rodrigues AP (2011) Mercury, copper and zinc contamination in soils and fluvial sediments from an abandoned gold mining area in southern Minas Gerais State, Brazil. Environ Earth Sci 64:211-222. doi:10.1007/s12665-010-0840-8

Chien LC, Hung TC, Choang KY, Yeh CY, Meng PJ, Shieh MJ, Han BC (2002) Daily intake of TBT, Cu, Zn, Cd and As for fishermen in Taiwan. Sci Total Environ 285(1):177-185

Copat C, Arena G, Fiore M, Ledda C, Fallico R, Sciacca S, Ferrante M (2013a) Heavy metals concentrations in fish and shellfish from eastern Mediterranean Sea: consumption advisories. Food Chem Toxicol 53:33-37. doi:10.1016/j.fct.2012.11.038

Copat C, Conti GO, Signorelli C, Marmiroli S, Sciacca S, Vinceti M, Ferrante M (2013b) Risk assessment for metals and PAHs by mediterranean seafood. Food Nut Sci 4(7A):10-13. doi:10.4236/fns.2013.47A002

D'Itri FM, D'Itri PA (1975) Progress Water Technol 7:223-227

Dabeka RW, McKenzie AD, Bradley P (2003) Survey of total mercury in total diet food composites and an estimation of the dietary intake of mercury by adults and children from two Canadian cities, 1998-2000. Food Addit Contam 20(7):629-638
Dabeka RW, McKenzie AD, Forsyth DS, Conacher HBS (2004) Survey of total mercury in some edible fish and shellfish species collected in Canada in 2002. Food Addit Contam 21(5):434-440

Donkor AK, Bonzongo JC, Nartey VK, Adotey DK (2006) Mercury in different environmental compartments of the Pra River Basin, Ghana. Sci Total Environ 368:164-176

Falandysz J, Dryżałowska A, Saba M, Wang J, Zhang D (2014) Mercury in the fairy-ring of Gymnopus erythropus (Pers.) and Marasmius dryophilus (Bull.) P. Karst. mushrooms from the Gongga Mountain, Eastern Tibetan Plateau. Ecotoxicol Environ Saf 104:18-22. doi:10.1016/j. ecoenv.2014.02.012

Golow AA, Adzei EA (2002) Mercury in surface soil and cassava crop near an alluvial goldmine at Dunkwa-on-Offin, Ghana. Bull Environ Contam Toxicol 69:228-235

Golow AA, Mingle LC (2002) Mercury in river water and sediments in some rivers near Dunkwa-on-Offin, an alluvial goldmine, Ghana. Bull Environ Contam Toxicol 70:379-384

Greenberg EA, Clesceri LS, Eaton AD (1992) Standard Methods for Examination of Water and Waste Water, 18th edn

Hamilton A (1971) Proc. Intern. Sympos. On mercury in man's environment. Prog Soc Conf Ottawa, p 87

Harris HH, Pickering IJ, George GN (2003) The chemical form of mercury in fish. Science 301:1203

Heinz GH, Hoffman DJ, Klimstra JD, Stebbins KR, Kondrad SL, Erwin CA (2011) Teratogenic effects of injected methylmercury on avian embryos. Environ Toxicol Chem 30(7):1593. doi:10.1002/etc.530

Hortellani MA, Sarkis JE, Menezes LC, Bazante-Yamaguishi R, Pereira AS, Garcia PF, Maruyama L, Castro PM (2013) Assessment of metal concentration in the billings reservoir sediments, São Paulo State, Southeastern Brazil. J Braz Chem Soc 24(1):58-67. doi:10.1590/S0103-50532013000100009

Hosseini SM, Mirghaffari N, Sufiani NM, Hosseini SV, Ghasemi AF (2013) Risk assessment of the total mercury in Golden gray mullet (Liza aurata) from Caspian Sea. Intl J Aquat Biol 1(6):258-265

JOINT FAO/WHO expert consultation on the risks and benefits of fish consumption (2010) health risks associated with fish consumption focus on methylmercury, dioxins and dioxin-like PCBS EC: RBFC/2010/3

Konig A, Bouzan C, Cohen JT, Connor WE, Kris-Etherton PM, Gray GM, Lawrence RS, Savitz DA, Teutsch SM (2005) A quantitative analysis of fish consumption and coronary heart disease mortality. Am J Prev Med 29:335-346

Kwaansa-Ansah E, Agorku S, Nriagu J (2011) Levels of total mercury in different fish species and sediments from the Upper Volta Basin at Yeji in Ghana. Bull Environ Contam Toxicol 86(4):406-409. doi:10.1007/ s00128-011-0214-2

Larceda LD, Salomons W (1991) Mercury in the Amazon. A chemical time bomb? Dutch Ministry of Housing, Physical planning and the environment. Hague

Larry B, Lobring, Billy BP (1991) Eds. Methods for the Determination of Metals in Environmental Samples. USEPA, p 266

Lecce SA, Pavlowsky RT (2014) Floodplain storage of sediment contaminated by mercury and copper from historic gold mining at Gold Hill, North Carolina, USA. Geomorphology 206:122-132

Limbong D, Kumampung J, Ayhuan D, Arai T, Miyazaki N (2005) Mercury pollution related to artisanal gold mining in north Sulawesi Island, Indonesia. Bull Environ Contam Toxicol 75:989-996

Marrugo-Negrete J, Benitez LN, Olivero-Verbel J (2008) Distribution of mercury in several environmental compartments in an aquatic ecosystem impacted by gold mining in northern Colombia. Arch Environ Contam Toxicol 55(2):305-316. doi:10.1007/s00244-007-9129-7

Martinez-Finley EJ, Aschner M (2014) Recent advances in mercury research. Curr Environ Health Rep 1(2):163-171. doi:10.1007/s40572-014-0014-z

Miller MB, Gustin MS, Eckley CS (2011) Measurement and scaling of airsurface mercury exchange from substrates in the vicinity of two Nevada gold mines. Sci Total Environ 409(19):3879-3886. doi:10.1016/j. scitotenv.2011.05.040

Morel FMM, Kraepiel AML, Amyot M (1998) Photooxidation of Hg(0) in an estuarine system. Annu Rev Ecol Syst 29:543-566

Müller G (1969) Index of geoaccumulation in the sediments of the Rhine River. Geoj 2(3):108-118

Nriagu JO, Pfeiffer WC, Malm O, Mierle G (1992) Mercury pollution in Brazil. Nature 356:389 
Olivero J, Solano B (1998) Mercury in environmental samples from a waterbody contaminated by gold mining in Colombia, South America. Sci Total Environ 217:83-89

Olivero J, Johnson B, Mendoza C, Paz R, Olivero R (2004) Mercury in the aquatic environment of the village of Caimito in the Mojana region, north of Colombia. Water Air Soil Pollut 159:409-420

Oppong SOB, Voegborlo RB, Agorku SE, Adimado AA (2010) Total Mercury in Fish, Sediments and Soil from the River Pra Basin, Southwestern Ghana. Bull Environ Contam Toxicol 85:324-329. doi:10.1007/s00128-010-0059-0

Palheta D, Taylor A (1995) Mercury in environmental and biological samples from a gold mining area in the Amazon region of Brazil. Sci Total Environ 168:63-69

Perkin Elmer (1994) Analytical Methods for Atomic Absorption Spectrophotometry, p 136

Pfeiffer WC, Larceda LD (1988) Mercury input into the Amazon region, Brazil. Environ Technol Lett 9:325-330

Rodrigues-Filho S, Maddock JEL (1997) Mercury pollution in two gold mining areas of the Brazilian Amazon. J Geoch Expl 58:231-240

Salomons W, Förstner U (1984) Metals in the hydrocycle. Springer, New York

Sonne C, Leifsson PS, Dietz R (2013) Liver and renal lesions in mercury contaminated narwhals (Monodon monoceros) from North West Greenland. Toxicol Environ Chem 95(3):1-14. doi:10.1080/02772248.2013.783666

Tchounwou PB, Ayensu WK, Ninashvili N, Sutton D (2003) Environmental exposure to mercury and its toxicopathologic implications for public health. Environ Toxicol 18:149-175

Thom T, Haase N, Rosamond W, Howard VJ, Rumsfeld J, Manolio T, Zheng ZJ, Flegal K, O'Donnell C, Kittner S, Lloyd-Jones D, Goff DC Jr, Hong Y, Adams R, Friday G, Furie K, Gorelick P, Kissela B, Marler J, Meigs J, Roger V, Sidney S, Sorlie P, Steinberger J, Wasserthiel-Smoller S, Wilson M, Wolf P (2006) Heart disease and stroke statistics-2006 update: a report from the American Heart Association Statistics Committee and Stroke Statistics Subcommittee. Circulation 113:e85-e151

Tomiyasu T, Kono Y, Kodamatani H, Hidayati N, Rahajoe JS (2013) The distribution of mercury around the small-scale gold mining area along the Cikaniki river, Bogor, Indonesia. Environ Res 125:12-19. doi:10.1016/j. envres.2013.03.015
Ullrich SM, Tanton TW, Abdrashitova SA (2001) Mercury in the aquatic environment: a review of factors affecting methylation. Crit Rev Environ Sci Technol 31(3):241-293

US-EPA (1989) Risk assessment guidance for superfund, vol. I. human health evaluation manual (Part A), Interim final. EPA 540/1-89/002. United States Environmental Protection Agency, Washington, DC

US-EPA (2000) Guidance for assessing chemical contamination data for use in fish advisories, vol. II. Risk assessment and fish consumption limits. EPA/823-B94-004. United States Environmental Protection Agency, Washington, DC

Virtanen JK, Voutilainen S, Rissanen TH, Mursu J, Tuomainen TP, Korhonen MJ, Valkonen VP, Seppanen K, Laukkanen JA, Salonen JT (2005) Mercury, fish oils, and risk of acute coronary events and cardiovascular disease, coronary heart disease, and all-cause mortality in men in eastern Finland. Arterioscler Thromb Vasc Biol 25:228-233

Wennberg M, Bergdahl IA, Stegmayr B, Hallmans G, Lundh T, Skerfving S, Stromberg U, Vessby B, Jansson JH (2007) Fish intake, mercury, long-chain $\mathrm{n}-3$ polyunsaturated fatty acids and risk of stroke in northern Sweden. $\mathrm{Br}$ J Nutr 98:1038-1045

Woods JS, Heyer NJ, Russo JE, Martin MD, Pillai PB, Farin FM (2013) Modification of neurobehavioral effects of mercury by genetic polymorphisms of metallothionein in children. Neurotoxicol Teratol 39:36-44. doi:10.1016/j. ntt.2013.06.004

World Health Organisation (1985) Environmental Pollution control in Relation to Development. WHO Experts Committees Report, Geneva, p 39

World Health Organisation (1990) Methylmercury. Environmental Health Criteria 101. World Health Organization, Geneva

Yoshizawa K, Rimm EB, Morris JS, Spate VL, Hsieh CC, Spiegelman D, Stampfer MJ, Willett WC (2002) Mercury and the risk of coronary heart disease in men. N Engl J Med 347:1755-1760

\section{Submit your manuscript to a SpringerOpen ${ }^{\circ}$ journal and benefit from:}

- Convenient online submission

- Rigorous peer review

- Immediate publication on acceptance

- Open access: articles freely available online

- High visibility within the field

- Retaining the copyright to your article

Submit your next manuscript at $>$ springeropen.com 